\title{
Study of the Communication Strategies Used by Malaysian ESL Students at Tertiary Level
}

\author{
Raed Latif Ugla \\ School of Educational Studies, Universiti Sains Malaysia \\ 11700 Gelugor, Penang, Malaysia \\ Nur Ilianis binti Adnan \\ School of Educational Studies, Universiti Sains Malaysia \\ 11700 Gelugor, Penang, Malaysia \\ E-mail: adnannurilianis@gmail.com \\ Mohamad Jafre Zainol Abidin \\ School of Educational Studies, Universiti Sains Malaysia \\ 11700 Gelugor, Penang, Malaysia \\ E-mail: jafre@usm.my
}

Received: November 15, 2012 Accepted: December 26, 2012 Published: December 27, 2012

doi:10.5296/ijele.v1i1.2962 URL: http://dx.doi.org/10.5296/ijele.v1i1.2962

\begin{abstract}
This study investigates the kinds of communication strategies (CSs) used by Malaysian ESL students. The data analysed in this study were collected in Universiti Sains Malaysia. The study was quantitative in nature where a questionnaire adopted from Dornyei and Scott's taxonomy of CSs (1995). This questionnaire was used to elicit the findings. The subject consisted of fifty Malaysia ESL students. The results obtained show different kinds of CSs used by Malaysia ESL students. The pedagogical and recommendations were provided in this study.
\end{abstract}

Keywords: Communication Skills, Communication Strategies (CSs), English as Second Language (ESL) 


\section{Introduction}

These days teaching and learning English is very important. The main objective of teaching English is to allow the learner to communicate orally and effectively. People around the world learn a foreign language to enable them to communicate effectively. The use of English as a first international communication means has grown for several decade (Graddol, 2006).

The strategies that are used by English as second language (ESL) learners to overcome the breakdowns during oral communication are known as communication strategies (CSs). The aim of this study is to identify the kinds of CSs used by Malaysia ESL students at tertiary level.

In the past years, the focus on teaching the four skills (writing, reading, listening and speaking) was the main target in teaching the foreign language but in recent years, the focus becomes more on the oral communication which includes listening and speaking skills. Rahman (2010) said that speaking is one of the most important ways to communicate, sometimes is used to express opinions, provide evidence, interpretations and transition of information, and the students need them to be able well in daily life and places of work. Mastering listening and speaking in foreign language enable what may be called the oral communication.

Some speakers use CSs when there is a problem to convey their ideas and thoughts in the second language (L2), this happens when the speakers cannot select or use the appropriate words, idioms, structures, phrases and so on. They face difficulties to communicate their thoughts in foreign language (FL), all these difficulties because lack of their communication competence. These strategies will help the speakers to reduce or remove their difficulties while transferring their thoughts and ideas to the others (Lam, 2006).

\section{Problem Statement}

This research will attempt to investigate the kinds of CSs used by Malaysian ESL students to give us a better understanding of their usage of these strategies when they communicate in English. Non-native speakers cannot master all words and phrases ad terminologies of the English language. When L2/foreign language speakers face difficulty in expressing their thoughts, because of their own limited resources of the target language, they use verbal and non-verbal means to help themselves to overcome the breakdown during oral communication. Speakers use CSs to ensure that the intended meaning they want to convey is understood (Tarone, 2005). Malaysian ESL students have some difficulties and problems, but the situation is different with them, for instance Malaysian ESL students use English during lessons time and also in daily functions as a means of communication with other people in their society. Although Malaysian ESL students communicate more in English, they still face with communication difficulties. Therefore, investigating CSs used by them through the communication tasks considers a crucial importance in terms of developing their oral communication skills. Lam (2007) claimed that 'it is a very important to know the problems of communication encountered ESL learners as well as CSs they use, to develop their communication skills." 


\section{Literature Review}

Corder (1978) defined CS as "a systematic technique practiced by the speakers when faced with difficulty to express the intended meaning." Faerch and Kasper (1983) defined CSs as "conscious plans to overcome the problems facing an individual to reach the intended meaning of communication process." Stern (1983) claimed that CSs are techniques, which can be used when there are difficulties in oral communication through (L2). The learners lack in L2 affects their use of CSs when they communicate orally in the target language. Second language speakers use CSs to help them to overcome some of the problems facing them in oral communication due to lack of their language proficiency. Communication strategies also help them achieve their communication in L2 (Dornyei \& Kormos, 1998).

Dornyei and Scott (1995) proposed their taxonomy of CSs which included most of CSs available in communication strategy (CS) research. According to Dornyei and Scott (1997), this taxonomy extended on the base of the taxonomies that developed by Tarone (1977) and Faerch and Kasper (1983) but it dealt with "how CSs help the speakers to solve the problems during oral communication tasks and accomplish mutual understanding." According to Dornyei and Scott (1997), these strategies achieve what may be called mutual understanding. Their classification were extended and collected on the base of CS research. Their taxonomy consisted of three main categories: direct strategies (strategies used by a speaker who faces problems during communication process), indirect strategies (strategies used by a speaker to provide the conditions that lead to the mutual understanding) and interactional strategies which referred to the mutual cooperation which make by two or more speakers to overcome the problems that face them through communication process.

Many factors that affect the use of CSs have been investigated and proposed by psychologists of education in the literature. Language proficiency, frequency of speaking English outside of the classroom and self-perceived English oral proficiency were the main factors that proposed in the literature which could affect the use of CSs.

Learners' level of language proficiency have been affected the use of CSs as mentioned in previous studies as in the Chen (1990) and Tuan (2001) studies. Learners who have different levels of proficiency in the target language are dependent on various sources of knowledge to overcome the problems they face in communicating (Chen, 1990). The same results were shown in his study that the learners who have high language proficiency used the CSs more effectively than those who have low proficiency. Chen (1990) and Tuan (2001) also stated that the learners who have high language proficiency used fewer strategies to communicate the intended meaning. However, they used some kinds of strategies in oral communication.

According to Nakatani (2006) students who have high oral proficiency use negotiation of meaning, fluency-oriented and social affective strategies, that are more effective to do the oral communication, because the students used them to stay conversation continuous and to gain interaction through negotiation. Students with low proficiency depended on ineffective strategies such as low activity listener and message abandonment strategies. This means that the learners who have high language competence were more ability to choose the strategies best suited to communicate in the target language through the use of their linguistic 
knowledge, while those who have low language competence were unable to do the same work done by the learners who have high language competence.

The use of English as means of communication more often outside the classroom helps the students or the learners to be able to use the suitable CSs. According to Clement (1986) the search for opportunities to increase the area of communication leads to the results of increased opportunities for communication between different significant intercultural.

Maliki (2010) conducted a study to show the importance of teaching CSs to L2 learners and to use them in effective way when they encounter communication problems through the oral communication process tasks. He reported that teaching CS is more important and he emphasised the need to introduce techniques that can be used to teach these strategies. The learners could use the techniques while they are interacting with other learners in a foreign language to get better communication. This study showed evidence about the use and the existence of CSs as a key element in the teaching of FL.

\section{Methodology}

This study will use survey design. According to Creswell (2009) survey design represents quantitative research procedures through which the researchers can administer a questionnaire to a group of participants who are the sample of the study. This study uses Dornyei and Scotts's taxonomy of CSs (1995) to elicit Malaysian ESL students' use of CSs.

The total population of students who study English in the School of Languages, Literacy, and Translation/ Universiti Sains Malaysia is 115 students. As for the research, 50 ESL students were chosen. It was convenience sampling in choosing the students.

To investigate the CSs used by Malaysian ESL students, the researcher used a quantitative method instrument, which is the questionnaire to achieve the above aim. The questionnaire is adopted from Dornyei and Scott's taxonomy of CSs (1995). The questionnaire is divided into three main categories (direct strategies, indirect strategies and interactional strategies). A five-point Likert type scale with the following weights ( $1=$ never use this strategy, $2=$ hardly ever use this strategy, $3=$ sometimes used this strategy, $4=$ often use this strategy and $5=$ always use this strategy) was used to get participants' responses for each strategy involved in this questionnaire. The duration of twenty minutes allowed for the participants to complete the questionnaire of CSs.

The data will be computed in the statistical package for social science (SPSS Statistic 17.0), which arises from the participants' respondents of the questionnaire. The researcher will compute the data to find out the mean, standard deviation, frequency and the percentage as well.

\section{Data Analysis and Results}

The questionnaire administered to a sample of 50 Malaysian ESL students at tertiary level. Descriptive statistical analyses of their responses to the survey items are shown in this section which addressed their use of CSs. The participants ranged between 18-20 years. 
The questionnaire administered to a sample of 50 Malaysian ESL students at tertiary level. Descriptive statistical analyses of their responses to the survey items are shown in this section. which addressed their use of CSs. The participants ranged between 18-20 years.

Table 1 shows the frequency of gender for Malaysian ESL students, there are 15 males (30.0) and 35 females (70.0) in the sample, giving a total of 50 responses.

Table 1. The frequency of gender for Malaysian ESL students

\begin{tabular}{|ll|l|l|l|l|}
\hline & & Frequency & Percent & Valid Percent & $\begin{array}{l}\text { Cumulative } \\
\text { Percent }\end{array}$ \\
\hline Valid & Male & 15 & 30.0 & 30.0 & 30.0 \\
& Female & 35 & 70.0 & 70.0 & 100.0 \\
& Total & 50 & 100.0 & 100.0 & \\
Missing & System & 0 & 0 & & \\
Total & 50 & 100.0 & & \\
\hline
\end{tabular}

Table 2 presents the means and standard deviations for each direct communication strategy used by Malaysian ESL students respectively. From the output shown in the table, the retrieval strategy gets the highest mean score $(\mathrm{M}=3.3800, \mathrm{SD}=1.24360)$, while the omission strategy gets the lowest mean score $(\mathrm{M}=2.4400, \mathrm{SD}=1.01338)$ among other direct strategies.

Table 2. The Means and Standard Deviation of Most Frequently Use of Direct CSs By Malaysian ESL Students

\begin{tabular}{|l|l|l|l|l|l|l|}
\hline Types of CSs & $\mathrm{N}$ & Range & Minimum & Maximum & Mean & $\begin{array}{l}\text { Std. } \\
\text { Deviation }\end{array}$ \\
\hline Retrieval & 50 & 4.00 & 1.00 & 5.00 & 3.3800 & 1.24360 \\
Use of all Purpose Words & 50 & 4.00 & 1.00 & 5.00 & 3.3600 & 1.36666 \\
Code-Switching & 50 & 3.00 & 1.00 & 5.00 & 3.1200 & 1.11831 \\
Circumlocution/Paraphrase & 50 & 4.00 & 1.00 & 5.00 & 3.0000 & 1.27775 \\
Message-Reduction & 50 & 4.00 & 1.00 & 5.00 & 3.0000 & 1.56492 \\
Self-Repair & 50 & 4.00 & 1.00 & 5.00 & 2.8800 & 1.18907 \\
Message-Replacement & 50 & 4.00 & 1.00 & 5.00 & 2.7200 & 1.32542 \\
Word-Coinage & 50 & 4.00 & 1.00 & 5.00 & 2.6200 & 1.12286 \\
Foreignizing & 50 & 4.00 & 1.00 & 5.00 & 2.5600 & 1.37262 \\
Omission & 50 & 4.00 & 1.00 & 5.00 & 2.5400 & 0.99406 \\
\hline
\end{tabular}




\begin{tabular}{|l|l|l|l|l|l|l|}
\hline Mime & 50 & 4.00 & 1.00 & 5.00 & 2.4600 & 0.78792 \\
Other Repairs & 50 & 4.00 & 1.00 & 5.00 & 2.4400 & 1.01338 \\
Restructuring & 50 & 4.00 & 1.00 & 5.00 & 2.3400 & 1.09935 \\
Approximation/Generalization & 50 & 4.00 & 1.00 & 5.00 & 2.3200 & 1.36187 \\
Self-Rephrasing & 50 & 4.00 & 1.00 & 5.00 & 2.1200 & 0.96129 \\
$\begin{array}{l}\text { Use of Similar Sounding } \\
\text { Word }\end{array}$ & 50 & 4.00 & 1.00 & 5.00 & 2.0400 & 1.10583 \\
Literal Translation & 50 & 4.00 & 1.00 & 5.00 & 1.9400 & 0.95640 \\
Mumbling & 50 & 3.00 & 1.00 & 4.00 & 1.4400 & 0.73290 \\
Valid N (listwise) & 50 & & & & & \\
\hline
\end{tabular}

Table 3 presents the means and standard deviations for each indirect communications strategy used by Malaysian ESL students respectively. From the output shown in the table, the use of fillers strategy gets the highest mean score $(M=3.9000, S D=1.14731)$, verbal strategy makers while the verbal strategy makers gets the lowest mean score $(M=2.4200, S D=1.14446)$ among other indirect strategies.

Table 3. The Means and Standard Deviation of Most Frequently Use of Indirect CSs By Malaysian ESL Students

\begin{tabular}{|c|c|c|c|c|c|c|}
\hline Types of CSs & $\mathrm{N}$ & Range & Minimum & Maximum & Mean & $\begin{array}{l}\text { Std. } \\
\text { Deviation }\end{array}$ \\
\hline Use of fillers & 50 & 4.00 & 1.00 & 5.00 & 3.9000 & 1.14731 \\
\hline $\begin{array}{l}\text { Feigning } \\
\text { Understanding }\end{array}$ & 50 & 3.00 & 1.00 & 4.00 & 2.6800 & 0.79385 \\
\hline $\begin{array}{l}\text { Self- } \\
\text { Repetition }\end{array}$ & 50 & 3.00 & 2.00 & 5.00 & 2.6600 & 0.68839 \\
\hline $\begin{array}{l}\text { Verbal Strategy } \\
\text { Makers } \\
\text { Valid N } \\
\text { (listwise) }\end{array}$ & $\begin{array}{l}50 \\
50\end{array}$ & 4.00 & 1.00 & 5.00 & 2.4200 & 1.14446 \\
\hline
\end{tabular}

Table 4 presents the means and standard deviations for each interactional communication strategy used by Malaysian ESL students respectively. From the output shown in the table, repair strategy gets the highest mean score $(\mathrm{M}=4.0200, \mathrm{SD}=1.37752)$ while the guessing strategy gets the lowest mean score $(\mathrm{M}=1.4800, \mathrm{SD}=0.95276)$ among other interactional 
strategies.

Table 4. The Means and Standard Deviation of Most Frequently Use of Interactional CSs By Malaysian ESL Students

\begin{tabular}{|l|l|l|l|l|l|l|}
\hline Types of CSs & $\mathrm{N}$ & Range & Minimum & Maximum & Mean & $\begin{array}{l}\text { Std. } \\
\text { Deviation }\end{array}$ \\
\hline Response: Repair & 50 & 4.00 & 1.00 & 5.00 & 4.0200 & 1.37752 \\
Asking for Clarification & 50 & 4.00 & 1.00 & 5.00 & 3.9800 & 0.86873 \\
Asking for confirmation & 50 & 4.00 & 1.00 & 5.00 & 3.1800 & 1.39518 \\
Indirect Appeal for Help & 50 & 4.00 & 1.00 & 5.00 & 3.1400 & 0.98995 \\
Response: Confirm & 50 & 2.00 & 2.00 & 4.00 & 3.0200 & 0.84491 \\
Response: Reject & 50 & 4.00 & 1.00 & 5.00 & 3.0000 & 1.29363 \\
Interpretive Summary & 50 & 3.00 & 2.00 & 5.00 & 2.9400 & 0.93481 \\
Asking for Repitition & 50 & 4.00 & 1.00 & 5.00 & 2.9400 & 1.40567 \\
Direct Appeal for help & 50 & 4.00 & 1.00 & 5.00 & 2.8800 & 1.00285 \\
Response: Repeat & 50 & 3.00 & 1.00 & 4.00 & 2.8200 & 0.66055 \\
Response: Rephrase & 50 & 4.00 & 1.00 & 5.00 & 2.8000 & 1.06904 \\
Own accuracy Check & 50 & 3.00 & 1.00 & 4.00 & 2.7400 & 0.77749 \\
Expressing Non- & 50 & 4.00 & 1.00 & 5.00 & 2.7400 & 1.06541 \\
Understanding & & & & & & \\
Response: Expand & 50 & 3.00 & 1.00 & 4.00 & 2.4600 & 0.90821 \\
Comprehension check & 50 & 4.00 & 1.00 & 5.00 & 2.0000 & 1.08797 \\
Guessing & 50 & 3.00 & 1.00 & 4.00 & 1.4800 & 0.95276 \\
Valid N (listwise) & 50 & \multicolumn{2}{|l}{} & & & \\
& & & & & \\
\hline
\end{tabular}

\section{Discussion}

\section{Kinds of CSs Used By Malaysia ESL Students at Tertiary Level}

Among different direct CSs strategies, Malaysian ESL students used retrieval, use of all purpose words, code-switching, circumlocution/paraphrase, message-reduction, message abandonment, self-repair, message-replacement, word-coinage, foreignizing and omission moderately. On the other hand, they used mime, other repairs, restructuring, approximation/generalisation, self-repairing, use of similar sounding word, literal translation and mumbling in a very low rate. It is believed that Malaysian ESL students have problem with poor vocabulary, since they use these strategies in low rate, and they also do not use non-verbal strategies more such as mime which is much more important strategy which keeps the conversation open when there is difficulty during communication task.

Among the indirect CSs, the Malaysian ESL students used fillers strategy more often than others. They used foreignizing understanding and self-repetition moderately. They use verbal strategy makers in a very low rate. The interactional CSs which used more often by them, namely response: repair and asking for clarification. They used the strategies namely: asking for confirmation, indirect appeal for help, response: confirm, response: reject, interpretive 
summary, asking for repetition, direct appeal for help, response: repeat, response: rephrase, own accuracy check and expressing non-understanding moderately. They used response: expand comprehension check and guessing in a very low rate. These evidences show that Malaysian ESL students use interactional strategies more than the other kinds of CSs to solve their difficulties during communication, since they have much more opportunities to use English in their every day life's functions and they also have more interaction situations with English speakers in their society. This supports the psycholinguistic theory developed by Faerch and Kasper (1983), which assumed that the speakers try o solve their communication breakdowns and difficulties through interaction, which goes through psychological process to reach the intended goal of communication. Table 5.0 (refer appendix) shows the kinds of CSs used by Malaysian ESL students.

Malaysian ESL students used mime strategy at low rate, which means that those students do not use their hands, facial expression, gestures and body movements during oral communication in the target language. Malaysian ESL students least frequently used self repair strategy, which means that those students do not have many grammatical mistakes, since this strategy associated with both grammar and linguistics aspects. Approximation strategy was another strategy least frequently used by Malaysian ESL students as this strategy uses to facilitate speech production by enabling the learners use an alternative word that generalises semantic features of the intended meaning.

\section{Conclusion}

This study aims to investigate CSs used by Malaysian ESL students at tertiary level. The result shows that Malaysian students did not face many difficulties or breakdowns during their communication in English because they use most of CSs in low level. This study suggests a need to incorporate CSs into the English language programs at different levels of education in order to enhance ESL students' ability in oral communication.

\section{Acknowledgement}

The authors would like to acknowledge all the authors of articles cited in this paper. In addition, the gratefully acknowledge USM, Universiti Sains Malaysia for their support and encouragement.

\section{References}

Bialystok, E., \& Kellerman, E. (1987). Language strategies in the classroom. In B. K. Das (Ed), Communication and learning in the classroom community.

Chen, S. Q. (1990). A Study of Communication Strategies in Interlanguage Production By Chinese EFL Learners. Language Learning, 40(2), 155-187. Retrieved September 19, 2011 from http://onlinelibrary.wiley.com/doi/10.1111/j.1467

Clement, R. (1986). Second Language Proficiency And Acculturation: An Investigation of The Effects of Language Status and Individual Characteristics. Journal of Language and Social Psychology 5, 271-290. 


\section{Macrothink}

International Journal of English Language Education

ISSN 2325-0887

2013, Vol. 1, No. 1

Corder, S. Q. (1978). Language-learner language. In Jack C. Richards (ed). Understanding Second and Foreign Language Learning. Rowley, Mass: Newbury House. pp. 71-91.

Creswell, J. W. (2009). Research Design: Qualitative, Quantitative, and Mixed Methods Approaches. Thousand Oaks, Calif: Sage Publications.

Dornyei, Z. (1995). On the Teachability of Communication Strategies. TESOL Quarterly, 29, $1,55-81$.

Dornyei, Z., \& Scott, M. L. (1997). Communication Strategies in A Second Language: Definitions and taxonomies. Language Learning, 47, 173-210. Retrieved September 19, 2011 from http://onlinelibrary.wiley.com/doi/10.1111/0023-8333.51997005/pdf

Dornyei, Z., \& Kormos, J. (1998). Problem-Solving Mechanisms in L2 Communication: A psycholinguistic Perspective. Studies in Second Language Acquistion, 20, 349-385.

Faerch. C., \& Kasper, G. (1983). Strategies in Interlanguage Communication. London: Longman.

Faerch. C., \& Kasper, G. (1983). Plans and Strategies in Foreign Language Communication. In Faerch, C., \& Kasper, G. (Eds.), Strategies in Interlanguage Communication. Harlow, England: Longman.

Graddol, David (2006). English Next: Why Global English May Mean the End of "English as a Foreign Language." London: British Council. Retrieved October 13, 2011 from http://www.britishcouncil.org/files/documents/learning-research-english

Lam, W. Y. K. (2006). Gaughing The Effects of ESL Oral Communication Strategy Teaching: A multi-method approach. e-FLT, 3(2), 142-157. Retrieved September 15, 2011 from e-flt.nus.edu.sg/v3n22006/lam.htm

Maleki, A. (2010). Techniques to Teach Communication Strategies. Journal of Language Teaching and Research, 1(5), 640-646.

Nakatani, Yasuo. (2006). Developing An Oral Communication Strategy Inventory. The modern Language Journal, 90, 151-168.

Rahman, M. Mojibur. (2010). Teaching Oral Communication Skills: A Task-based Approach. ESP World, Issue 1(27), Volume 9. Retrieved September 22, 2011 from http://www.esp-world.info

Stern, H. (1983). Fundamental Concepts of Language Teaching. Oxford: Oxford University Press.

Tarone, E. (1977). Conscious Communication Strategies in Interlanguage: A Progress Report. On TESOL 1977. Washington, D.C: TESOL.

Tarone, E. (2005). Speaking in a second language. In E. Hinkel (Ed.), Handbook of research in second language teaching and learning. pp. 485-502.

Tuan, H. J. (2001). Is Extroversion-Intriversion Tendency A Variable in The Choice of 


\section{Macrothink}

International Journal of English Language Education ISSN 2325-0887 2013, Vol. 1, No. 1

Strategies in Communication? Proceedings of the Eighteenth Conference on English Teaching and Learning in the Republic of China Taipei: Crane. pp. 306-324.

\section{Copyright Disclaimer}

Copyright reserved by the author(s).

This article is an open-access article distributed under the terms and conditions of the Creative Commons Attribution license (http://creativecommons.org/licenses/by/3.0/). 